\title{
Temporal and intra-population patterns in polar bear foraging ecology in western Hudson Bay
}

\author{
Amy C. Johnson ${ }^{1, *}$, Keith A. Hobson ${ }^{2}$, Nicholas J. Lunn ${ }^{3}$, David McGeachy ${ }^{3}$, \\ Evan S. Richardson ${ }^{4}$, Andrew E. Derocher ${ }^{1}$ \\ ${ }^{1}$ Department of Biological Sciences, University of Alberta, Edmonton, AB T6G 2E9, Canada \\ ${ }^{2}$ Department of Biology, Western University, London, ON N6A 5B7, Canada \\ ${ }^{3}$ Environment and Climate Change Canada, CW-422 Biological Sciences Building, University of Alberta, Edmonton, \\ AB T6G 2E9, Canada \\ ${ }^{4}$ Environment and Climate Change Canada, Winnipeg, MB R3C 4W2, Canada
}

\begin{abstract}
Climate-mediated sea ice declines have led to alterations in ecosystem composition, phenology, and primary productivity, potentially altering trophic dynamics in Arctic marine ecosystems. As one of the Arctic's top predators and a species dependent on sea ice habitat for survival, polar bears Ursus maritimus are at risk of habitat loss from sea ice declines, and therefore have been used to monitor the effects of climate change in the Arctic. We used stable isotope $\left(\delta^{15} \mathrm{~N}, \delta^{13} \mathrm{C}\right)$ values of 806 hair samples collected from Western Hudson Bay $(\mathrm{WH})$ polar bears from 1993-1994 and 2004-2016 to examine variations in isotopic niche size and diet within the population, patterns in foraging ecology over time, and the relationship between hair isotopic values and sea ice dynamics. We found significant variation in isotopic values between age- and sex-classes. Adult males had the highest $\delta^{15} \mathrm{~N}$ and $\delta^{13} \mathrm{C}$ values and the largest isotopic niches, reflecting broader diets. In contrast, adult females (with and without cubs) and subadults differed isotopically from adult males, and their relatively smaller isotopic niches potentially make them more vulnerable to habitat change. Population $\delta^{15} \mathrm{~N}$ values significantly increased over time from 1993 (mean \pm SD: $18.8 \pm 0.5 \%$ ) to $2016\left(19.5 \pm 0.7 \%\right.$ ), while $\delta^{13} \mathrm{C}$ values significantly decreased from $1993(-16.2 \pm 0.3 \%)$ until $2011(-17.7 \pm 0.2 \%)$ before increasing until $2016(-17.0 \pm 0.3 \%)$. Values of $\delta^{13} \mathrm{C}$ were significantly correlated with length of the open-water period, suggesting that this apex predator's foraging ecology was affected by climate change. We suggest that WH polar bears may have undergone a significant dietary niche shift and/or that the baseline isotopic values in this ecosystem may have changed over the last $25 \mathrm{yr}$ in response to climate change.
\end{abstract}

KEY WORDS: Stable isotopes · Polar bear · Ursus maritimus · Foraging ecology · Arctic marine ecology $\cdot$ Western Hudson Bay

\section{INTRODUCTION}

The Arctic has experienced rapid warming at a rate 2-3 times the global mean (Post et al. 2009, Franzke et al. 2017), which has resulted in significant and continuing sea ice decline (Comiso 2012, Stern \& Laidre 2016). Climatic change is expected to affect the structure and function of Arctic marine ecosys-

*Corresponding author: acj1@ualberta.ca tems (Van der Putten et al. 2010), and species whose life history is dependent on sea ice habitat are particularly vulnerable to continued warming (Laidre et al. 2008, Post et al. 2009, Søreide et al. 2010). Arctic marine mammals depend upon sea ice to varying degrees for various aspects of their life history and are therefore sensitive to climate change-induced sea ice loss (Laidre et al. 2008).

(C) The authors 2019. Open Access under Creative Commons by Attribution Licence. Use, distribution and reproduction are unrestricted. Authors and original publication must be credited. 
Ecological responses to climate change that may affect Arctic marine mammals fall into 3 broad categories: alterations in species composition, phenology, and primary productivity. First, changes to ecosystem composition are mainly due to range shifts or species extirpation in response to increasing temperatures (Van der Putten et al. 2010). Arctic sea ice loss has led to altered distributions of some ice-associated marine mammals with subarctic species expected to expand their ranges northward (Laidre et al. 2008), which can influence food web dynamics (Bluhm \& Gradinger 2008, Gaston et al. 2012). Secondly, climate change can affect the timing of life history events, which may lead to a disconnect between trophic levels, with implications for foraging ecology and predator-prey dynamics (Van der Putten et al. 2010). Arctic sea ice decline alters the phenology of primary productivity, which can lead to a trophic mismatch with zooplankton grazers, with cascading effects on higher trophic level species such as marine mammals (Laidre et al. 2008, Søreide et al. 2010). Further, loss of sea ice may result in declines in sympagic (ice-associated) algae that produces up to $57 \%$ of overall Arctic marine primary productivity with links through the food web to marine mammals (Brown et al. 2018). Lastly, sea ice decline has resulted in a longer open-water season and an increase in Arctic annual primary productivity due to the longer growing season for pelagic phytoplankton (Arrigo et al. 2008). Because sympagic algae forms the base of the Arctic marine food web, loss of sea ice will alter where marine productivity occurs in the Arctic and may affect the foraging ecology of higher trophic levels (Søreide et al. 2010, Leu et al. 2011, Brown et al. 2018). Understanding marine mammal foraging in response to climate change can provide insights into Arctic food web shifts and ecosystem dynamics.

Hudson Bay is near the southern limit of polar bear Ursus maritimus distribution and has experienced the effects of climate warming before many other Arctic areas (Stirling et al. 1999, McKinney et al. 2009, Lunn et al. 2016). The Hudson Bay ecosystem has undergone rapid change due to changing sea ice phenology, including a shorter on-ice foraging period and longer onshore fasting period for polar bears (Stirling et al. 1999, Thiemann et al. 2008, Castro de la Guardia et al. 2017). As top predators, polar bears may shift their diet in response to the availability of ringed seals Pusa hispida and bearded seals Erignathus barbatus, both ice-dependent species, and open-water seals (e.g. harbour seals Phoca vitulina) due to variation in sea ice conditions (Thiemann et al. 2008, Young \& Ferguson 2014). Long-term life his- tory data has documented decreased body condition, survival, reproduction, and abundance in the Western Hudson Bay population (WH) in recent decades (Stirling et al. 1999, Regehr et al. 2007, Lunn et al. 2016), suggesting that the WH may be experiencing climate-related changes in foraging ecology.

In western Hudson Bay, earlier sea ice breakup and longer ice-free periods threaten polar bears (Regehr et al. 2007, Castro de la Guardia et al. 2013, Stern \& Laidre 2016) because they are highly specialized predators that rely on the sea ice for movement and access to energy rich ice-associated seals, especially during the spring which is an important season for foraging before fasting during the open-water period (Stirling \& Archibald 1977). In Hudson Bay, ringed seals are the primary prey of polar bears and also depend on sea ice habitat, while bearded seals, harp seals Pagophilus groenlandicus, harbour seals, and beluga whales Delphinapterus leucas are occasional prey (Thiemann et al. 2008). Because polar bears depend on sea ice as a platform from which to forage, an increase in the duration of the openwater period can influence their foraging ecology and therefore body condition, survival, reproduction, and population persistence (Stirling et al. 1999, Regehr et al. 2007, Lunn et al. 2016). The open-water period is an important monitoring metric for polar bears because of their dependence upon sea ice habitat, but the open-water period has increased by $>4$ wk in western Hudson Bay in the past 3.5 decades (Stern \& Laidre 2016).

We used biomarkers of diet to study the foraging ecology of WH polar bears during the critical spring/ early summer period when they are largely inaccessible. Stable isotope analysis (SIA), primarily involving the use of stable nitrogen $\left(\delta^{15} \mathrm{~N}\right)$ and carbon $\left(\delta^{13} \mathrm{C}\right)$ isotope ratios, has been used to study foraging ecology (e.g. Hilderbrand et al. 1996, Young \& Ferguson 2014), trophic interactions (Hobson \& Welch 1992), and to estimate the diet of polar bears (Cherry et al. 2011, Rogers et al. 2015). In marine systems, $\delta^{15} \mathrm{~N}$ values increase trophically (DeNiro \& Epstein 1981) whereas $\delta^{13} \mathrm{C}$ values indicate benthic versus pelagic and nearshore versus offshore sources of primary production (Hobson \& Welch 1992). Guard hair (outer layer of hair) $\delta^{13} \mathrm{C}$ and $\delta^{15} \mathrm{~N}$ values can provide insights into the foraging ecology of bears (Hilderbrand et al. 1996, Hobson et al. 2000), reflecting the spring/early summer molt period when polar bear hair is produced (St. Louis et al. 2011). Changes in environmental conditions can alter baseline isotopic values in marine systems and these changes can be passed onto higher trophic levels (Lowther et al. 


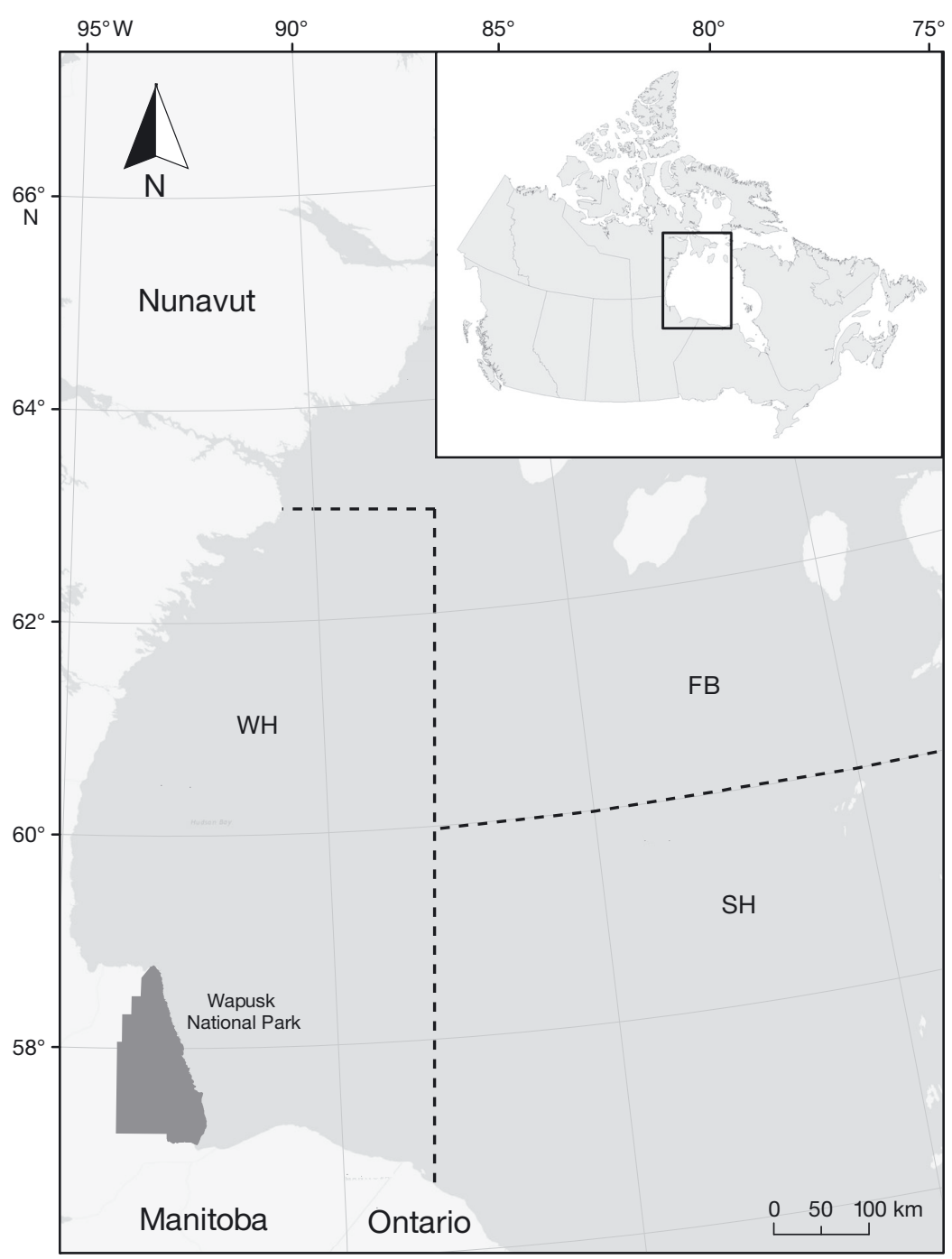

Fig. 1. Western Hudson Bay, Canada, showing Wapusk National Park and adjacent areas where polar bears were captured in 1993-1994 and 2004-2016. Dashed lines: management boundaries of the Western Hudson Bay (WH), Southern Hudson Bay (SH) and Foxe Basin (FB) polar bear populations (Peacock et al. 2010)

2017). As such, stable isotope analyses, especially when applied through time, can reveal changes in ecosystem responses to perturbations such as climate change. Despite long-term monitoring of polar bears in Hudson Bay, the investigation of diet and linkages to the food web have not been examined using $\mathrm{WH}$ polar bear hair stable isotopes.

We used $\delta^{15} \mathrm{~N}$ and $\delta^{13} \mathrm{C}$ analysis for WH polar bears to determine (1) whether there are within-population dietary differences related to age and sex; $(2)$ whether polar bear foraging ecology has changed over time from samples collected in 1993-1994 and 2004-2016; and (3) if there is a relationship between temporal variation in foraging ecology and changes in sea ice phenology.

\section{MATERIALS AND METHODS}

\subsection{Study area}

Hudson Bay (Fig. 1) is a shallow inland sea (Jones \& Anderson 1994) that is ice-covered from January-April but ice-free from August-October/ November (Maxwell 1986, Castro de la Guardia et al. 2017). Three polar bear populations occur in Hudson Bay: Foxe Basin, Southern Hudson Bay, and WH (Peacock et al. 2010). The 3 populations overlap on the sea ice during the ice-cover period, but are largely segregated from one another during the ice-free period due to fidelity to terrestrial summering areas (Peacock et al. 2010).

\subsection{Sample collection and preparation}

Polar bears were captured in Wapusk National Park and adjacent areas in Manitoba, Canada from August to early October in 1993-1994 and 20042016. They were located by helicopter, captured using standard chemical immobilization techniques (Stirling et al. 1989), and individually marked using numbered ear tags and permanent lip tattoos. Sex and reproductive status were recorded, and age was determined from counts of cementum annuli within an extracted vestigial premolar (Calvert \& Ramsay 1998) or in the field for dependent offspring based on tooth eruption patterns. We classified adults as $\geq 5 \mathrm{yr}$ old and subadults as $3-5$ yr old. Dependent offspring (cubs-of-the-year, yearlings, and 2 yr old cubs captured with mother) and juveniles $(<3 \mathrm{yr}$ old $)$ were excluded from analyses because of the complexities of maternal transfer (Polischuk et al. 2001) and dependence on maternal dietary input (Stirling 1974). Adult females with and without cubs were analyzed separately to assess if there was a difference in stable isotope values between these 2 groups. Thus, there were 5 age/sex classes used in the analyses: adult males, adult females with young, solitary adult females, subadult females, and subadult males. Guard hair samples for SIA were collected from a 
shaved patch on the rump approximately $15 \mathrm{~cm}$ lateral to the tail. We obtained 806 hair samples from 559 individual polar bears (Table S1 in Supplement 1 at www.int-res.com/articles/suppl/619p187 supp.pdf). The mean $( \pm \mathrm{SE})$ number of samples $\mathrm{yr}^{-1}$ was $54 \pm 6.0$ (range: 17-106). There were 397 females, 409 males, 699 adults, and 107 subadults. All capture and handling methods were conducted in accordance with the Canadian Council on Animal Care (www.ccac.ca) guidelines and approved by the University of Alberta BioSciences Animal Care and Use Committee and Environment and Climate Change Canada's Western and Northern Animal Care Committee. Research was conducted under wildlife research permits issued by the Government of Manitoba and by the Parks Canada Agency.

Surface contaminants (e.g. fat, skin, dirt) on the guard hair samples were removed with a clean scalpel and the hair was then washed in $500 \mathrm{ml}$ milliQ water with 6 drops of Ivory dish soap at $40^{\circ} \mathrm{C}$, rinsed thoroughly, and then dried overnight. Each dried sample was cut into small pieces from which $1 \mathrm{mg}$ was placed into a tin capsule (Rogers et al. 2015). Values of $\delta^{13} \mathrm{C}$ and $\delta^{15} \mathrm{~N}$ were determined via combustion in a EuroVector EA3028-HT elemental analyzer (Eurovector) at $1030^{\circ} \mathrm{C}$ coupled to a GV Instruments IsoPrime (Manchester) continuous-flow isotope ratio mass spectrometer. Internal laboratory standards NIST 8415 whole egg powder standard reference material $\left(\delta^{15} \mathrm{~N}=6.89 \%, \delta^{13} \mathrm{C}=-23.99 \%\right.$ ) were placed for every 20 unknowns in sequence. Values are reported in the standard $\delta$-notation relative to atmospheric nitrogen (Air) and Vienna Pee Dee belemnite limestone for $\delta^{15} \mathrm{~N}$ and $\delta^{13} \mathrm{C}$, respectively. Based on within-run replicate measurements of standards, we estimate analytical precision to be $\pm 0.2 \%$ for $\delta^{15} \mathrm{~N}$ and $\pm 0.1 \%$ for $\delta^{13} \mathrm{C}$. SIA was conducted at the Biogeochemical Analytical Service Laboratory at the University of Alberta, Edmonton, Canada.

\subsection{Age- and sex-related patterns}

We used Kruskal-Wallis tests to determine whether there were significant differences in $\delta^{15} \mathrm{~N}$ and $\delta^{13} \mathrm{C}$ values among age/sex classes and post hoc Dunn's tests when significant differences were detected.

The package Stable Isotope Bayesian Ellipses in $\mathrm{R}$ (SIBER) was used to compare isotopic niche size and overlap among age/sex classes (Jackson et al. 2011, Young \& Ferguson 2014, Yurkowski et al. 2016). Isotopic niches are a subset of ecological niches and can be used to study differences in foraging ecology between groups (Layman et al. 2007, Jackson et al. 2011). We used the isotopic niche size to indicate the diversity of prey in the predator's diet, where a larger isotopic niche size reflects a broader prey diversity (Jackson et al. 2011, Yurkowski et al. 2016). For each group, approximately $40 \%$ of the isotopic data was encompassed to create the standard ellipse with a standard ellipse area corrected for small sample sizes $\left(\mathrm{SEA}_{\mathrm{C}}\right.$ ) to plot the isotopic niche (Jackson et al. 2011, Young \& Ferguson 2014, Yurkowski et al. 2016). We then calculated the percentage overlap in isotopic niches between groups (Jackson et al. 2011, Young \& Ferguson 2014, Yurkowski et al. 2016). We estimated the isotopic niche size using a Bayesian technique (iterations: 50 000; burn-in: 10000 ; thin: 10; Markov chain Monte Carlo [MCMC] chains: 2; covariance matrix prior: inverse Wishart; means prior: vague normal) to determine the mode standard ellipse area and $95 \%$ credible interval $\left(\mathrm{SEA}_{\mathrm{B}}\right)$ (Jackson et al. 2011, Yurkowski et al. 2016). Lastly, we quantitatively compared isotopic niche sizes among age/sex classes and among years by calculating the probability that a group's posterior distribution of ellipse area was smaller than that of the other groups (i.e. the proportion of posterior distributions that were smaller) (Yurkowski et al. 2016). Unlike previous methods of estimating the isotopic niche width that were sensitive to sample size bias (i.e. convex hull), the standard ellipse area is calculated using a Bayesian technique and thus allows for robust quantitative comparisons between groups with different sample sizes (Jackson et al. 2011).

\subsection{Temporal patterns}

We used linear regression to assess the relationship between $\delta^{15} \mathrm{~N}$ values and year. Due to the observed pattern of a decrease then increase in $\delta^{13} \mathrm{C}$ values, we used a broken stick regression to determine the breakpoint in $\delta^{13} \mathrm{C}$ values over time; linear regression analyses were conducted to examine the relationship between $\delta^{13} \mathrm{C}$ values and year before and after the breakpoint. To determine if the effect of year differed among age/sex classes, we used multiple linear regression to analyze the relationship between $\delta^{15} \mathrm{~N}$ and $\delta^{13} \mathrm{C}$ values and age/sex class, year, and the interaction of these 2 factors. In addition, we used SIBER to compare the population's isotopic niches for each year from 1993-1994 and 2004-2016 to further evaluate trends in foraging over time. SIBER was also used to compare the yearly isotopic niches for adult females and adult males separately. 


\subsection{Relationship between bear isotopic values and sea ice cover}

We calculated annual dates of sea ice breakup and freeze-up for the WH management zone portion (Fig. 1) of Hudson Bay from $25 \times 25 \mathrm{~km}$ resolution passive microwave satellite raster imagery from the National Snow and Ice Data Center in Boulder, Colorado (Cavalieri et al. 1996). Date of breakup was defined as the first ordinal date in spring on which sea ice concentration was $\leq 50 \%$ for 3 consecutive days and date of freeze-up as the first ordinal date in autumn on which sea ice concentration was $\geq 10 \%$ for 3 consecutive days (Etkin 1991, Stirling et al. 1999, Lunn et al. 2016). We derived the variable 'open-water period' as a proxy for the length of time bears spend onshore by subtracting date of breakup from date of freeze-up and then subtracting $25 \mathrm{~d}$ because bears typically come ashore 20-30 d after the $50 \%$ breakup date (Stirling et al. 1999, Castro de la Guardia et al. 2017). Pearson's correlation analyses were used to examine the relationship between foraging ecology (mean yearly $\delta^{15} \mathrm{~N}$ values, mean yearly $\delta^{13} \mathrm{C}$ values, or yearly isotopic niche sizes) and the sea ice variable (length of the open-water period).

We used Shapiro-Wilk's tests for normality of all variables. When non-normally distributed (ShapiroWilk $\mathrm{p} \leq 0.05)$, non-parametric tests were used if standard transformations ( $\log _{10}$ and square root) did not normalize the data: Kruskal-Wallis tests were used to analyze $\delta^{15} \mathrm{~N}$ and $\delta^{13} \mathrm{C}$ values among age/sex classes, while $\log _{10}$ transformation was used to normalize yearly isotopic niche size. All statistical analyses were conducted in $\mathrm{R}$ v.3.4.0 (R Core Team 2017).

\subsection{Stable isotope mixing models}

We created stable isotope mixing models to estimate the contributions of various prey species to the diet of WH polar bears (Inger et al. 2006, Cherry et al. 2011, Rogers et al. 2015). Mixing models were created using the package Bayesian Mixing Models in R (MixSIAR), which uses Bayesian methods to estimate possible diet combinations as probability distributions (iterations: 1000 000; burn-in: 500000 ; thinned by 500) (Stock \& Semmens 2016). We obtained prey isotopic information from published data on species that constitute WH polar bear diet (Thiemann et al. 2008): ringed seal muscle (mean \pm SD of adults and pups from 2006: $\delta^{15} \mathrm{~N}=13.8 \pm 0.7 \%$ o, $\delta^{13} \mathrm{C}=-20.0 \pm$
0.5\%), harbour seal muscle (pups from 1999-2006: $\delta^{15} \mathrm{~N}=16.3 \pm 1.0 \% ; \delta^{13} \mathrm{C}=-19.7 \pm 0.8 \%$ ) , bearded seal muscle (pups from 2005-2006: $\delta^{15} \mathrm{~N}=16.8 \pm$ $0.9 \%$; $\delta^{13} \mathrm{C}=-18.1 \pm 0.3 \%$ ) (Young et al. 2010), and harp seal muscle (from 1996: $\delta^{15} \mathrm{~N}=13.5 \pm 0.7 \%$; $\delta^{13} \mathrm{C}=-18.0 \pm 0.5 \%$ ) (Hammill et al. 2005). Muscle was used because it was the most common tissue type available for prey stable isotope data and the protein from prey muscle tissue would be routed to the polar bear protein metabolic pathway (Cherry et al. 2011). Trophic enrichment factors (TEFs) were included in mixing models to account for the difference in isotope values between a predator's tissue and its diet (Rode et al. 2016). Diet-to-hair TEFs of $4.5 \pm 1.51 \%$ o (SD) for $\delta^{15} \mathrm{~N}$ (brown bears Ursus arctos; Rode et al. 2016) and $2.23 \pm 1.86 \%$ for $\delta^{13} \mathrm{C}$ (estimated using the package Stable Isotope Discrimination Estimation in R [SIDER]; Healy et al. 2017) were used in the mixing models.

\section{RESULTS}

\subsection{Age- and sex-related patterns}

Values of $\delta^{15} \mathrm{~N}$ were significantly different among age/sex classes (Kruskal-Wallis $\chi^{2}=406.0$, $\mathrm{df}=4, \mathrm{p} \leq$ 0.001 ). There was a significant difference in $\delta^{15} \mathrm{~N}$ values between all comparisons of age/sex classes except between subadult females and subadult males. Adult males had significantly higher hair $\delta^{15} \mathrm{~N}$ values than all other classes, solitary adult females had significantly higher $\delta^{15} \mathrm{~N}$ values than subadults, and adult females with young had significantly lower $\delta^{15} \mathrm{~N}$ values than all other classes (Table 1; Table S2 in Supplement 2). Similarly, $\delta^{13} \mathrm{C}$ values were significantly different among age/sex classes (KruskalWallis $\chi^{2}=46.9$, df $=4, \mathrm{p} \leq 0.001$ ). Adult males had significantly higher $\delta^{13} \mathrm{C}$ values than all other classes while there were no significant differences in $\delta^{13} \mathrm{C}$ values among the other age/sex classes (Table 1; Table S3 in Supplement 2).

There was variation in percentage overlap of isotopic niches between age/sex classes. Adult females with and without young overlapped to a high degree $(79 \%)$. However, adult females with young overlapped less with adult males (50\%) than did solitary adult females $(75 \%)$. Adult males overlapped the least with subadults $(43-44 \%)$, whereas subadult males and subadult females overlapped the most with each other $(81 \%)$ (Fig. S1, Table S4 in Supplement 2). Isotopic niche sizes of adult males and adult females (solitary and with young) were larger (0.7- 
$0.8 \%^{2}$ ) than isotopic niche sizes of subadult males and subadult females $\left(0.5 \%{ }^{2}\right)$ (Table 1 ; Fig. S1). All age classes had a high probability of their isotopic niche size being smaller than adult males: adult females with young $(72 \%)$, solitary adult females $(97 \%)$, subadult males $(99.8 \%)$, and subadult females $(99.9 \%)$ (Fig. S1). The probability of the isotopic niche size of solitary adult females being smaller than adult females with young was high $(91 \%)$. Solitary adult females and adult females with young had a high probability of their isotopic niche size being larger than subadult males (93 and 99\%, respectively). Similarly, solitary adult females and adult females with young had a high probability of their isotopic niche size being larger than subadult females (95 and 99.7\%, respectively). Lastly, the probability of the isotopic niche size of subadult females being smaller than subadult males was intermediate $(49 \%)$.

Table 1. Median $\delta^{15} \mathrm{~N}$ values and $\delta^{13} \mathrm{C}$ values \pm median absolute deviation (\%) and the isotopic niche sizes (i.e. mode standard ellipse area [SEA $\left.\mathrm{S}_{\mathrm{B}}\right]$ ) with its $95 \%$ credible interval (95\% CI) for each age/sex class of Western Hudson Bay polar bears. Significant differences are indicated by superscript letters (groups with different letters were significantly different from each other; Dunn's test $\mathrm{p} \leq 0.05$; Tables S2 \& S3 in Supplement 2 at www.int-res.com/articles/suppl/619p187_supp.pdf)

\begin{tabular}{|lcccc|}
\hline Age/sex class & $\mathrm{n}$ & $\delta^{15} \mathrm{~N}(\%)$ & $\delta^{13} \mathrm{C}(\%)$ & $\mathrm{SEA}_{\mathrm{B}}(95 \% \mathrm{CI})\left(\%{ }^{2}\right)$ \\
\hline Adult female with young & 218 & $18.8 \pm 0.4^{\mathrm{a}}$ & $-17.3 \pm 0.5^{\mathrm{a}}$ & $0.8(0.7,0.9)$ \\
Solitary adult female & 117 & $19.3 \pm 0.4^{\mathrm{b}}$ & $-17.3 \pm 0.5^{\mathrm{a}}$ & $0.7(0.5,0.8)$ \\
Adult male & 364 & $19.8 \pm 0.5^{\mathrm{c}}$ & $-17.0 \pm 0.6^{\mathrm{b}}$ & $0.8(0.7,0.9)$ \\
Subadult female & 62 & $19.1 \pm 0.5^{\mathrm{d}}$ & $-17.2 \pm 0.4^{\mathrm{a}}$ & $0.5(0.4,0.6)$ \\
Subadult male & 45 & $19.0 \pm 0.3^{\mathrm{d}}$ & $-17.2 \pm 0.5^{\mathrm{a}}$ & $0.5(0.4,0.7)$ \\
\hline
\end{tabular}

\subsection{Temporal patterns}

There was a significant increase in $\delta^{15} \mathrm{~N}$ values from 1993 (mean \pm SD: $18.8 \pm 0.5 \%)$ to $2016(19.5 \pm 0.7 \%$ ), with a peak in $2014(19.7 \pm 0.6 \%)$ (Fig. $2 \mathrm{~A}_{\text {; }}$ linear regression, $\left.\mathrm{R}^{2}=0.07, F_{1,804}=57.2, \mathrm{p}<0.001\right)$. A similar pattern was noted when data from 2004-2016 were analyzed separately. The broken stick regression indicated a breakpoint in $\delta^{13} \mathrm{C}$ values in 2011: $\delta^{13} \mathrm{C}$ values decreased significantly from $1993(-16.2 \pm 0.3 \%)$ to $2011\left(-17.7 \pm 0.2 \%\right.$ ) (Fig. $2 B_{\text {; }}$ linear regression, $R^{2}=$ $\left.0.5, F_{1,575}=521.8, \mathrm{p}<0.001\right)$ then increased significantly from 2011 to $2016(-17.0 \pm 0.3 \%$ ) (Fig. 2B; linear regression, $\left.\mathrm{R}^{2}=0.2, F_{1,294}=94.3, \mathrm{p}<0.001\right)$. We found that there were no significant interactions for the effects of age/sex class and year on $\delta^{15} \mathrm{~N}\left(\mathrm{R}^{2}=0.46\right.$, $\left.F_{7,798}=96.04, \mathrm{p}>0.05\right)$ and $\delta^{13} \mathrm{C}$ values $\left(\mathrm{R}^{2}=0.27\right.$, $F_{7,798}=41.93, \mathrm{p}>0.05$ ) and therefore the effect of year did not differ among age/sex classes.

Isotopic niche sizes differed among years: isotopic niche size was highest in 2005, 2006, and 2008, and was lowest in the 1990s and 2011-2013 (Figs. S2 \& S3 in Supplement 3). Years 1993 and 1994 had high probabilities of their isotopic niche sizes being smaller than most years $(>69 \%$, except when compared to each other and 2011-2013) (Table S5 in Supplement 3).
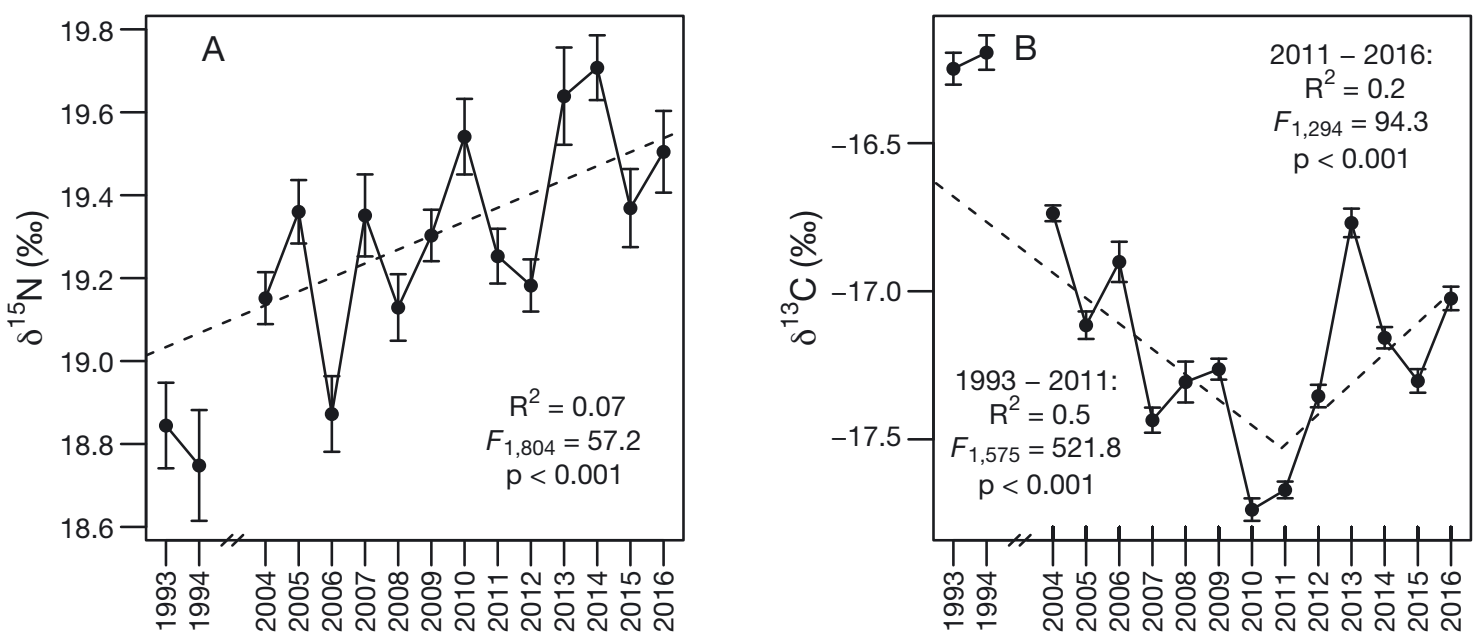

Fig. 2. Mean $( \pm \mathrm{SE})(\mathrm{A}) \delta^{15} \mathrm{~N}$ and $(\mathrm{B}) \delta^{13} \mathrm{C}$ values for Western Hudson Bay polar bears in each year (1993-1994, 2004-2016). Dashed lines: regression line for the relationship between $(\mathrm{A}) \delta^{15} \mathrm{~N}$ values and year and (B) $\delta^{13} \mathrm{C}$ values and year before and after the breakpoint in 2011 
Similarly, 2011-2013 had high probabilities of their isotopic niche sizes being smaller than most years (>60\%, except when compared to each other, 1993, and 1994). In contrast, 2005, 2006, and 2008 had high probabilities of their isotopic niche sizes being larger than most years $(>95 \%$, except when compared to each other). The isotopic niche sizes of adult females were largest in 2005, 2006, and 2010, and smallest in 2013 (Figs. S4 \& S5 in Supplement 3). Similarly, the isotopic niche sizes of adult males were largest in 2004 and 2005, and smallest in the 1990s and 2013 (Figs. S4 \& S5).

\subsection{Relationship between bear isotopic values and sea ice cover}

The mean yearly bear $\delta^{13} \mathrm{C}$ values were significantly negatively correlated with the length of the open-water period (Pearson's correlation, $t=-2.4, \mathrm{p}=$ $0.03, \mathrm{r}=-0.6 ;$ Fig. 3 ). The mean yearly bear $\delta^{15} \mathrm{~N}$ values and the mode yearly $\mathrm{SEA}_{\mathrm{B}}$ values (i.e. isotopic niche sizes) were not significantly correlated with the length of the open-water period (Pearson's correlation, $\mathrm{p}>0.05$ ).

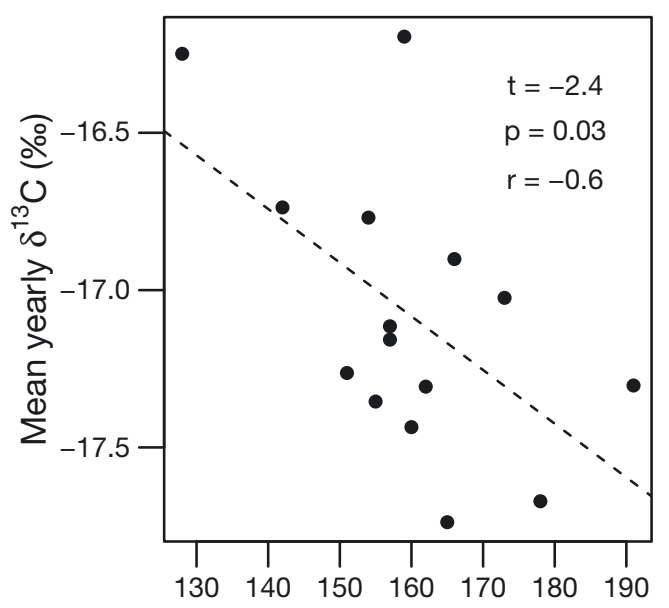

Length of the open-water period (d)

Fig. 3. Significant correlation between mean yearly $\delta^{13} \mathrm{C}$ values for Western Hudson Bay polar bears and the length of the open-water period (Pearson's correlation $\mathrm{p} \leq 0.05$ )

\subsection{Stable isotope mixing models}

Ringed seals ( $49 \%$ ) comprised the majority of the overall population diet, followed by harbour seals $(20 \%)$, bearded seals $(19 \%)$, then harp seals $(12 \%)$. Ringed seals were the largest component of the diet for adult females with young $(67 \%)$, solitary adult females $(51 \%)$, subadult females $(59 \%)$, and subadult males $(53 \%)$, as well as a large part of the diet of adult males (28\%) (Table 2). Harbour seals were the largest part of the diet of adult males (32\%) and were relatively high contributions to the diet of solitary adult females $(20 \%)$, subadult females $(16 \%)$, and subadult males $(18 \%)$. Adult males had higher proportions of bearded seals $(29 \%)$ than the other age/sex classes $(<20 \%)$. Harp seals were generally low in the diet for all age classes $(<14 \%)$.

Ringed seals were estimated to be lowest in bear diet in the 1990s (17-21\%) and highest in 2008 (72\%) (Fig. 4, Table S6 in Supplement 3). Harbour seals comprised lower proportions of the diet in the 1990s $(3 \%)$, then increased in the diet over time after 2009 $(>15 \%)$. Bearded seals comprised a large part of the diet in the 1990s (23-24\%), decreased in 2004-2007 $(<20 \%)$, then increased in $2008(26 \%)$ and 2013 $(29 \%)$. Harp seals contributed a larger proportion to the diet in the 1990s and 2004-2005 (29-56\%) but were a smaller proportion of the diet in most years $(<22 \%)$.

\section{DISCUSSION}

We found significant variation in polar bear hair $\delta^{15} \mathrm{~N}$ and $\delta^{13} \mathrm{C}$ values both within the $\mathrm{WH}$ and over time from 1993-2016, as well as a correlation between $\delta^{13} \mathrm{C}$ values and sea ice dynamics. Our results suggest that (1) the food web baseline (i.e. primary producer) isotope values have changed, (2) the Hudson Bay ecosystem has changed (e.g. food web reorganization), (3) there have been alterations in polar 


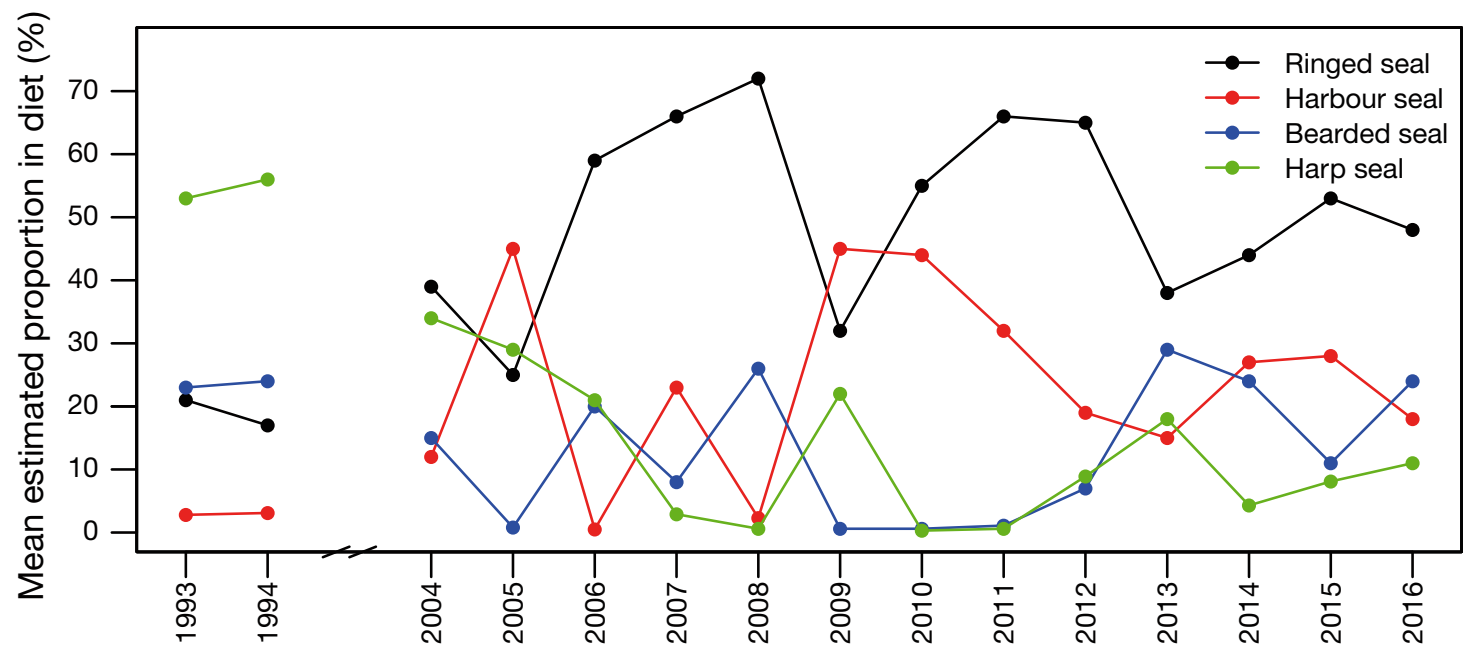

Fig. 4. Mean estimated proportion (\%) of each prey item in the diet of Western Hudson Bay polar bears (all age/sex classes) in each year from the stable isotope mixing model

bear foraging ecology, and/or (4) there have been changes to polar bear fasting.

\subsection{Age- and sex-related patterns}

Adult males had the highest $\delta^{15} \mathrm{~N}$ (median $0.5-1 \%$ higher) and $\delta^{13} \mathrm{C}$ values (median $0.2-0.3 \%$ higher), and largest isotopic niche size compared to the other age/sex classes, as well as the lowest amounts of isotopic niche overlap with the other classes. Higher hair $\delta^{15} \mathrm{~N}$ values may result from differences in diet; for example, the consumption of bearded seal pups in western Hudson Bay which have higher $\delta^{15} \mathrm{~N}$ values (muscle mean: 16.8\%) than other prey (Young et al. 2010). Similarly, the higher $\delta^{13} \mathrm{C}$ values of adult male polar bears suggests they are consuming higher proportions of prey with a benthic source, such as bearded seals (McKinney et al. 2009). These results are consistent with Thiemann et al. $(2008,2011)$, who used quantitative fatty acid signature analysis of WH polar bears and showed that adult males consumed more bearded seals than other age/sex classes. Similarly, our mixing model estimated that adult males consumed more bearded seals and harbour seals than the other age/sex classes. Additionally, bearded seals and harbour seals use broken ice areas (Cameron \& Boveng 2009, Bajzak et al. 2013), which is habitat used more by adult male polar bears, and adult males hunt larger prey than other bears (Stirling \& Derocher 1990). Furthermore, spatial differences between males and females may have influenced isotopic values, whereby the use of coastal/ nearshore areas by adult males in the summer may have increased their $\delta^{15} \mathrm{~N}$ and $\delta^{13} \mathrm{C}$ values relative to females in inland areas. We also found that adult males had a larger isotopic niche size than other bears. A similar finding was noted by Thiemann et al. (2011) and indicates that adult males have a more generalist and broader foraging strategy than adult females and subadults that rely mainly on ringed seals. A more generalist foraging strategy may enable adult males to hunt a larger range of prey than other age/sex classes and allow them to alter foraging behaviour in response to changes in prey availability (Thiemann et al. 2011). In contrast, as a consequence of having a narrower range of prey in their diet, adult females and subadults may be at greater risk from changes in prey availability due to sea ice loss (Thiemann et al. 2011). Lastly, adult males may have higher $\delta^{15} \mathrm{~N}$ values because during the spring breeding season their primary activity is mating (Stirling et al. 2016) so they hunt less and are more dependent on fasting, which, in extreme cases, can increase $\delta^{15} \mathrm{~N}$ values (Hobson et al. 1993).

Adult female reproductive status influenced both $\delta^{15} \mathrm{~N}$ values and isotopic niche size, most likely as a result of the physiological demands of gestation and lactation. Solitary females may have mated in the spring and were potentially pregnant during the fall capture. Reproductive female black bears Ursus americanus have more than twice the rate of protein loss as nonreproductive females (Harlow et al. 2002); thus, pregnant female polar bears in our study may have consumed more muscle to increase their protein intake to support reproduction, leading to an increase in their hair $\delta^{15} \mathrm{~N}$ values. Lactation by females with cubs may also lead to lower $\delta^{15} \mathrm{~N}$ values (Polis- 
chuk et al. 2001). Alternatively, the significantly higher $\delta^{15} \mathrm{~N}$ values of solitary females $(19.3 \%$ ) suggests that they are feeding at a higher trophic level than females with young $(18.8 \%$ o). However, there was no significant difference in $\delta^{13} \mathrm{C}$ values between adult females with or without young, suggesting little variation in the carbon sources of the prey consumed; that is, similar proportions of benthic-feeding prey (bearded seals) versus pelagic-feeding prey (ringed, harbour, and harp seals) (McKinney et al. 2009). Therefore, the variation in $\delta^{15} \mathrm{~N}$ values between females with and without cubs may reflect differences in the proportion of pelagic-feeding species in their diets. For example, ringed seal pups have the lowest $\delta^{15} \mathrm{~N}$ values of western Hudson Bay seal species (Young et al. 2010) and female polar bears with cubs rely on ringed seal pups (Stirling et al. 1993), which would result in their having lower hair $\delta^{15} \mathrm{~N}$ values. This is supported by our mixing model result that adult females with young consumed higher proportions of ringed seals than solitary females, while solitary females consumed more harbour seals than adult females with young. Furthermore, adult females with young had a larger isotopic niche size (indicating a more generalist foraging strategy) than solitary adult females. The number and age of the cubs may influence the mother's habitat use and foraging behaviour due to different energetic requirements and hunting abilities of the accompanying cubs (Stirling 1974, Stirling et al. 1993, Sciullo et al. 2017). Future research on isotopic patterns of family groups (females with different numbers of cubs and cubs of different ages) would improve our understanding of variation in foraging ecology within $\mathrm{WH}$. Females with cubs may have a wider range of foraging strategies (e.g. scavenging), which would increase dietary variation (Thiemann et al. 2011, Sciullo et al. 2017). In contrast, solitary adult females had smaller isotopic niche sizes, suggesting that they targeted particular resources (Yurkowski et al. 2016). These females would not be constrained by cubs and could therefore forage optimally to maximize energy gain without needing to avoid infanticidal males (Stirling et al. 1993) or open water. Lastly, larger overlap between solitary adult females and adult males in isotopic niches and diet suggests similarities in foraging ecology. In contrast, the lower amount of isotopic niche and dietary overlap between adult females with young and adult males is consistent with their occupying different areas and isotopic niche spaces.

Differences in isotopic values between adults and subadults suggests that $\mathrm{WH}$ polar bears differ in their foraging ecology based on age class, provided isotopic discrimination between diet and hair is independent of age. The intermediate $\delta^{15} \mathrm{~N}$ values for subadults (males: 19.0\%; females: 19.1\%) suggests that they may have fed at lower trophic levels than adult males $(19.8 \%)$, potentially reflecting increased predation of juvenile ringed seals (which have midrange $\delta^{15} \mathrm{~N}$ values; mean: $13.8 \%$ ) (Young et al. 2010). The smaller isotopic niches of subadult polar bears suggest they are limited in their prey, likely because of their lack of hunting experience. Thiemann et al. (2011) also found that subadults had narrower diets than adults and suggested that subadults foraged mainly on ringed seals, with little scavenging on other prey. In contrast, adults had larger isotopic niches than subadults, indicating that they had greater variation in foraging ecology. The larger isotopic niche of adults may be the result of the spatial separation and thus prey differences between adult females and males (Stirling et al. 1993) as well as the ability of adults to adopt different foraging strategies in response to changes in prey availability (Thiemann et al. 2011). Subadult females and subadult males had high isotopic niche overlap with each other, which indicates that they occupy similar isotopic niche spaces. Subadults had the most amount of isotopic niche overlap with solitary adult females and secondly with adult females with young, which is similar to Thiemann et al.'s (2011) results and our mixing model estimates that these groups rely heavily on ringed seals. In contrast, there was low overlap between subadults and adult males, which may be because adult males kleptoparasitize subadults (Stirling 1974), and subadults may therefore avoid adult males, resulting in different isotopic niche spaces.

\subsection{Temporal patterns and sea ice}

The Hudson Bay ecosystem underwent a regime shift after the mid-1990s as a consequence of warming-induced distribution shifts of forage fish (Gaston et al. 2003, 2012). Subsequent dietary shifts from Arctic cod Boreogadus saida towards sub-Arctic species such as capelin Mallotus villosus and sandlance Ammodytes sp. have been observed in lower trophic level predators such as thick-billed murres Uria lomvia (Gaston et al. 2003) and ringed seals (Young \& Ferguson 2014, Yurkowski et al. 2016). Similarly, the lengthening of the open-water period due to sea ice decline in the Arctic supports an increase in subArctic marine mammals such as harbour seals (Florko et al. 2018). 
The variation in the WH polar bear population's yearly isotopic niche size may reflect differences in the diversity of polar bear prey over time. Larger isotopic niches in 2005, 2006, and 2008 suggest that a larger variety of prey were consumed. The larger isotopic niche sizes corresponded with higher proportions of harbour/harp seals in the diet of female polar bears in 2004/2005 (Sciullo et al. 2017), similar to our mixing model results of higher proportions of harbour seals in 2005, harp seals in 2005/2006, and bearded/ringed seal in 2008 relative to most other years. We found that WH polar bears had smaller isotopic niche sizes in the 1990s and 2011-2013, which indicates lower prey diversity. Similarly, our mixing model results and Sciullo et al. (2017) indicate that certain species dominated the diet in those years (ringed seals in 2011/2012 and bearded/harp seals in 2013). The isotopic niche sizes of adult females and adult males showed a similar pattern as the overall population, with larger isotopic niches in the early 2000s followed by a decline until 2013. We found that adult females had larger isotopic niches than males in 2010, while Sciullo et al. (2017) also reported that adult female diet had an increase in bearded and harp seals in 2010. While we found the overall population's isotopic niche size increased slightly after 2013, the isotopic niche sizes of adult females and adult males both initially increased in 2014 but then declined, suggesting a decrease in dietary variation in more recent years.

Temporal changes in hair stable isotope values may be associated with 4 different processes that are not necessarily mutually exclusive: (1) changes in the food web baseline isotope values (primary producers); (2) ecosystem changes (e.g. reorganization of the food web); (3) alterations in polar bear foraging ecology; and/or (4) changes in the duration and intensity of fasting. However, data required to conclusively differentiate between these hypotheses is lacking. Nonetheless, we found that isotopic values in WH polar bears changed from the early 1990s to 2016. First, the observed increase in hair $\delta^{15} \mathrm{~N}$ values may reflect an increase in the baseline (primary producer) $\delta^{15} \mathrm{~N}$ values over this period (McKinney et al. 2009, Yurkowski et al. 2016, Lowther et al. 2017). For example, Yurkowski et al. (2016) showed that $\delta^{15} \mathrm{~N}$ values in ringed seal muscle throughout the Arctic increased from 1990 to 2011 (e.g. from 16.1 to $17.3 \%$ in Resolute, Nunavut, Canada), which was attributed to the effect of sea ice variability on prey availability. Increased polar bear $\delta^{15} \mathrm{~N}$ values may thus have been driven by prey $\delta^{15} \mathrm{~N}$ value increases or may have been similarly influenced by changes to prey avail- ability. Alternatively, increasing $\delta^{15} \mathrm{~N}$ values of hair may indicate that WH polar bears may be feeding at a higher trophic level more recently (mean in 2014: $19.7 \%$ ) than in the early 1990s (mean in 1994: $18.7 \%$ ). For instance, harbour seals in western Hudson Bay had higher $\delta^{15} \mathrm{~N}$ values (mean: $16.3 \%$ ) than ringed seals (mean: 13.8\%) (Young et al. 2010) and the increase in polar bear $\delta^{15} \mathrm{~N}$ values over time may reflect increased consumption of harbour seals. This hypothesis is supported by our mixing model estimates of higher proportions of harbour seals in the diet over time. Changes in sea ice conditions may affect prey availability, as harbour seals increased and ringed seals decreased in WH polar bear diet from 1994 to 1998, which was correlated with earlier breakup (Iverson et al. 2006). Furthermore, harbour seals increased in abundance as sea ice cover declined in western Hudson Bay from 1996 to 2016 (Florko et al. 2018). Lastly, higher $\delta^{15} \mathrm{~N}$ values have also been associated with fasting (Hobson et al. 1993) and WH polar bears have been reported to be spending more time on land, without access to prey, because of earlier breakup and later freeze-up (Stirling et al. 1999, Regehr et al. 2007, Lunn et al. 2016), potentially leading to an increase in $\delta^{15} \mathrm{~N}$ values.

Similar to hair $\delta^{15} \mathrm{~N}$ values, changes in bear hair $\delta^{13} \mathrm{C}$ values over time may be the result of shifts in lower trophic level dynamics and/or polar bear foraging ecology (McKinney et al. 2009, Yurkowski et al. 2016, Lowther et al. 2017). The temporal pattern of $\delta^{13} \mathrm{C}$ values was more variable than $\delta^{15} \mathrm{~N}$ and was correlated with the open-water period. Firstly, the highest $\delta^{13} \mathrm{C}$ values in the 1990s suggest a focus on benthic-foraging prey (e.g. bearded seals) (McKinney et al. 2009), and high $\delta^{13} \mathrm{C}$ values were associated with a shorter open-water period (which would increase access to ice-associated prey). These results correspond with the mixing model estimates of high proportions of bearded seals in the 1990s. Secondly, the decrease in $\delta^{13} \mathrm{C}$ values from the 1990s (mean: $-16.2 \%$ ) to 2010 (mean: $-17.7 \%$ ) suggests a shift towards more pelagic-foraging prey (McKinney et al. 2009), coinciding with higher proportions of harp seals in WH female diets (Sciullo et al. 2017) and harbour seals from our results in 2010. Thirdly, the increase in bear $\delta^{13} \mathrm{C}$ values in 2013 (mean: -16.8\%o) indicates more benthic-foraging prey, which corresponds with a decline in ringed seal density and pup recruitment in western Hudson Bay (Young et al. 2015, Ferguson et al. 2017). Similarly, our diet estimates and Sciullo et al. (2017) indicate a decrease in ringed seals and increase in bearded seals in 2013 
diets. Lastly, $\delta^{13} \mathrm{C}$ values decreased again after 2013 (mean: $-17.3 \%$ ), suggesting further dietary shifts towards pelagic species. Lower bear $\delta^{13} \mathrm{C}$ values were correlated with a longer open-water period, similar to the relationship between lower polar bear $\delta^{13} \mathrm{C}$ values and earlier sea ice breakup in western Hudson Bay (McKinney et al. 2009). Further, these results suggest that sea ice decline may drive shifts in polar bear foraging ecology between ice-associated and open-water prey, which will likely continue as the open-water period increases (Thiemann et al. 2008).

The change in the Hudson Bay ecosystem composition over our study period may have influenced the observed temporal patterns in WH polar bear $\delta^{15} \mathrm{~N}$ values, $\delta^{13} \mathrm{C}$ values, isotopic niche size, and dietary estimates. We found that temporal patterns in polar bear isotopic values were related to phenological changes in western Hudson Bay. Sea ice phenology drives ecosystem processes in the Arctic, such as iceassociated algae production (Sibert et al. 2010), with consequences for the foraging ecology of higher trophic levels (Søreide et al. 2010, Brown et al. 2018). Furthermore, sea ice decline and subsequent changes to Arctic primary productivity may lead to a shift from a sea ice-dominated ecosystem towards a pelagic ecosystem (Leu et al. 2011), thus affecting polar bear prey availability and Arctic trophic interactions. The WH population has experienced declines in reproduction, survival, and abundance (Stirling et al. 1999, Regehr et al. 2007, Lunn et al. 2016) and future climate projections predict earlier breakup and later freeze-up (Castro de la Guardia et al. 2013), which have the potential to further alter WH polar bears and Hudson Bay food web dynamics. SIA can be a powerful method for monitoring ecological dynamics in the changing Arctic. However, there are challenges associated with this technique, including the ability to separate shifts in predator diet from changes in lower trophic levels (e.g. baseline shifts or changes in prey species). Polar bear isotopic values may therefore be a useful but complex tool for monitoring changes in Arctic trophic dynamics, which would benefit from additional data on the food web baseline and changes in prey isotopic values over time to better understand ecosystem changes. Climate change-induced sea ice loss is predicted to continue to affect Arctic marine ecosystem structure and biodiversity. Research employing stable isotope analysis at multiple trophic levels will provide more refined means to detect potential changes in food web structure and foraging ecology of individual species in this rapidly changing ecosystem.
Acknowledgements. Financial and logistical support of field research was provided by ArcticNet, Canadian Association of Zoos and Aquariums, Canadian Circumpolar Institute, the Churchill Northern Studies Centre, Canadian Wildlife Federation, Care for the Wild International, Earth Rangers Foundation, Environment and Climate Change Canada, EnviroNorth, Hauser Bears, the Isdell Family Foundation, Kansas City Zoo, Manitoba Conservation, Manitoba Sustainable Development, Natural Sciences and Engineering Research Council of Canada, Northern Science Training Program, Parks Canada Agency, Pittsburgh Zoo Conservation Fund, Polar Bears International, Quark Expeditions, Schad Foundation, the University of Alberta, Wildlife Media Inc., World Wildlife Fund Arctic Programme, World Wildlife Fund (Canada), and W. Garfield Weston Foundation. We also thank the 5 anonymous reviewers for their valuable comments that improved the manuscript.

\section{LITERATURE CITED}

Arrigo KR, van Dijken G, Pabi S (2008) Impact of a shrinking Arctic ice cover on marine primary production. Geophys Res Lett 35:L19603

* Bajzak CE, Bernhardt W, Mosnier A, Hammill MO, Stirling I (2013) Habitat use by harbour seals (Phoca vitulina) in a seasonally ice-covered region, the western Hudson Bay. Polar Biol 36:477-491

Bluhm BA, Gradinger R (2008) Regional variability in food availability for Arctic marine mammals. Ecol Appl 18: S77-S96

*Bown TA, Galicia MP, Thiemann GW, Belt ST, Yurkowski DJ, Dyck MG (2018) High contributions of sea ice derived carbon in polar bear (Ursus maritimus) tissue. PLOS ONE 13:e0191631

Calvert W, Ramsay MA (1998) Evaluation of age determination of polar bears by counts of cementum growth layer groups. Ursus 10:449-453

Cameron M, Boveng P (2009) Habitat use and seasonal movements of adult and sub-adult bearded seals. Alaska Fish Sci Cent Q Rep 2009:1-4

Castro de la Guardia L, Derocher AE, Myers PG, Terwisscha van Scheltinga AD, Lunn NJ (2013) Future sea ice conditions in western Hudson Bay and consequences for polar bears in the 21st century. Glob Change Biol 19: 2675-2687

Castro de la Guardia L, Myers PG, Derocher AE, Lunn NJ, Terwisscha van Scheltinga AD (2017) Sea ice cycle in western Hudson Bay, Canada, from a polar bear perspective. Mar Ecol Prog Ser 564:225-233

Cavalieri DJ, Parkinson CL, Gloersen P, Zwally HJ (1996) Sea ice concentrations from Nimbus-7 SMMR and DMSP SSM/I-SSMIS passive microwave data, version 1 (updated yearly, 1978-2016). NASA National Snow and Ice Data Center Distributed Active Archive Center, Boulder, $\mathrm{CO}$

Cherry SG, Derocher AE, Hobson KA, Stirling I, Thiemann GW (2011) Quantifying dietary pathways of proteins and lipids to tissues of a marine predator. J Appl Ecol 48: 373-381

Comiso JC (2012) Large decadal decline of the Arctic multiyear ice cover. J Clim 25:1176-1193

* DeNiro MJ, Epstein S (1981) Influence of diet on the distribution of nitrogen isotopes in animals. Geochim Cosmochim Acta 45:341-351 
Etkin DA (1991) Break-up in Hudson Bay: its sensitivity to air temperatures and implications for climate warming. Climatol Bull 25:21-34

Ferguson SH, Young BG, Yurkowski DJ, Anderson R, Willing C, Nielsen O (2017) Demographic, ecological, and physiological responses of ringed seals to an abrupt decline in sea ice availability. PeerJ 5:e2957

Florko KRN, Bernhardt W, Breiter CJC, Ferguson SH, Hainstock M, Young BG, Petersen SD (2018) Decreasing sea ice conditions in western Hudson Bay and an increase in abundance of harbour seals (Phoca vitulina) in the Churchill River. Polar Biol 41:1187-1195

Franzke CLE, Lee S, Feldstein SB (2017) Evaluating Arctic warming mechanisms in CMIP5 models. Clim Dyn 48: 3247-3260

Gaston AJ, Woo K, Hipfner JM (2003) Trends in forage fish populations in northern Hudson Bay since 1981, as determined from the diet of nestling thick-billed murres Uria lomvia. Arctic 56:227-233

Gaston AJ, Smith PA, Provencher JF (2012) Discontinuous change in ice cover in Hudson Bay in the 1990s and some consequences for marine birds and their prey. ICES J Mar Sci 69:1218-1225

Hammill MO, Lesage V, Carter P (2005) What do harp seals eat? Comparing diet composition from different compartments of the digestive tract with diets estimated from stable-isotope ratios. Can J Zool 83:1365-1372

Harlow HJ, Lohuis T, Grogan RG, Beck TDI (2002) Body mass and lipid changes by hibernating reproductive and nonreproductive black bears (Ursus americanus). J Mammal 83:1020-1025

*Healy K, Guillerme T, Kelly SBA, Inger R, Bearhop S, Jackson AL (2017) SIDER: an R package for predicting trophic discrimination factors of consumers based on their ecology and phylogenetic relatedness. Ecography 41:1393-1400

*Hilderbrand GV, Farley SD, Robbins CT, Hanley TA, Titus K, Servheen C (1996) Use of stable isotopes to determine diets of living and extinct bears. Can J Zool 74: 2080-2088

Hobson KA, Welch HE (1992) Determination of trophic relationships within a high Arctic marine food web using $\delta^{13} \mathrm{C}$ and $\delta^{15} \mathrm{~N}$ analysis. Mar Ecol Prog Ser 84:9-18

Hobson KA, Alisauskas RT, Clark RG (1993) Stable-nitrogen isotope enrichment in avian tissues due to fasting and nutritional stress: implications for isotopic analyses of diet. Condor 95:388-394

Hobson KA, McLellan BN, Woods JG (2000) Using stable carbon $\left(\delta^{13} \mathrm{C}\right)$ and nitrogen $\left(\delta^{15} \mathrm{~N}\right)$ isotopes to infer trophic relationships among black and grizzly bears in the upper Columbia River basin, British Columbia. Can J Zool 78: 1332-1339

Inger R, Ruxton GD, Newton J, Colhoun K, Robinson JA, Jackson AL, Bearhop S (2006) Temporal and intrapopulation variation in prey choice of wintering geese determined by stable isotope analysis. J Anim Ecol 75: 1190-1200

Iverson SJ, Stirling I, Lang SLC (2006) Spatial, temporal, and individual variation in the diets of polar bears across the Canadian Arctic: indicators of changes in prey populations and environment. In: Boyd IL, Wanless S, Camphuysen CJ (eds) Top predators in marine ecosystems: their role in monitoring and management. Cambridge University Press, Cambridge, p 98-117

Jackson AL, Inger R, Parnell AC, Bearhop S (2011) Com- paring isotopic niche widths among and within communities: SIBER-Stable Isotope Bayesian Ellipses in R. J Anim Ecol 80:595-602

Jones EP, Anderson LG (1994) Northern Hudson Bay and Foxe Basin: water masses, circulation and productivity. Atmos-Ocean 32:361-374

* Laidre KL, Stirling I, Lowry LF, Wiig Ø, Heide-Jørgensen MP, Ferguson SH (2008) Quantifying the sensitivity of Arctic marine mammals to climate-induced habitat change. Ecol Appl 18:S97-S125

Layman CA, Quattrochi JP, Peyer CM, Allgeier JE (2007) Niche width collapse in a resilient top predator following ecosystem fragmentation. Ecol Lett 10:937-944

* Leu E, Søreide JE, Hessen DO, Falk-Petersen S, Berge J (2011) Consequences of changing sea-ice cover for primary and secondary producers in the European Arctic shelf seas: timing, quantity, and quality. Prog Oceanogr 90:18-32

Kowther AD, Fisk A, Kovacs KM, Lydersen C (2017) Interdecadal changes in the marine food web along the west Spitsbergen coast detected in the stable isotope composition of ringed seal (Pusa hispida) whiskers. Polar Biol 40: 2027-2033

* Lunn NJ, Servanty S, Regehr EV, Converse SJ, Richardson E, Stirling I (2016) Demography of an apex predator at the edge of its range: impacts of changing sea ice on polar bears in Hudson Bay. Ecol Appl 26:1302-1320

Maxwell JB (1986) A climate overview of the Canadian inland seas. In: Martini IP (ed) Canadian inland seas. Elsevier Science, Amsterdam, p 79-99

McKinney MA, Peacock E, Letcher RJ (2009) Sea ice-associated diet change increases the levels of chlorinated and brominated contaminants in polar bears. Environ Sci Technol 43:4334-4339

Peacock E, Derocher AE, Lunn NJ, Obbard ME (2010) Polar bear ecology and management in Hudson Bay in the face of climate change. In: Ferguson SH, Loseto LL, Mallory ML (eds) A little less Arctic: top predators in the world's largest northern inland sea. Springer, New York, NY, p 93-115

Polischuk SC, Hobson KA, Ramsay MA (2001) Use of stablecarbon and-nitrogen isotopes to assess weaning and fasting in female polar bears and their cubs. Can J Zool 79: 499-511

*Post E, Forchhammer MC, Bret-Harte MS, Callaghan TV and others (2009) Ecological dynamics across the Arctic associated with recent climate change. Science 325: 1355-1358

R Core Team (2017) R: a language and environment for statistical computing. R Foundation for Statistical Computing, Vienna

Regehr EV, Lunn NJ, Amstrup SC, Stirling I (2007) Effects of earlier sea ice breakup on survival and population size of polar bears in western Hudson Bay. J Wildl Manag 71: 2673-2683

Rode KD, Stricker CA, Erlenbach J, Robbins CT and others (2016) Isotopic incorporation and the effects of fasting and dietary lipid content on isotopic discrimination in large carnivorous mammals. Physiol Biochem Zool 89: 182-197

Rogers MC, Peacock E, Simac K, O'Dell MB, Welker JM (2015) Diet of female polar bears in the southern Beaufort Sea of Alaska: evidence for an emerging alternative foraging strategy in response to environmental change. Polar Biol 38:1035-1047 
Sciullo L, Thiemann GW, Lunn NJ, Ferguson SH (2017) Intraspecific and temporal variability in the diet composition of female polar bears in a seasonal sea ice regime. Arctic Sci 3:672-688

Sibert V, Zakardjian B, Saucier F, Gosselin M, Starr M, Senneville S (2010) Spatial and temporal variability of ice algal production in a 3D ice-ocean model of the Hudson Bay, Hudson Strait and Foxe Basin system. Polar Res 29: 353-378

Søreide JE, Leu E, Berge J, Graeve M, Falk-Petersen S (2010) Timing of blooms, algal food quality and Calanus glacialis reproduction and growth in a changing Arctic. Glob Change Biol 16:3154-3163

St Louis VL, Derocher AE, Stirling I, Graydon JA and others (2011) Differences in mercury bioaccumulation between polar bears (Ursus maritimus) from the Canadian high- and sub-Arctic. Environ Sci Technol 45: 5922-5928

Stern HL, Laidre KL (2016) Sea-ice indicators of polar bear habitat. Cryosphere 10:2027-2041

Stirling I (1974) Midsummer observations on the behavior of wild polar bears (Ursus maritimus). Can J Zool 52: 1191-1198

Stirling I, Archibald WR (1977) Aspects of predation of seals by polar bears. J Fish Res Board Can 34:1126-1129

Stirling I, Derocher AE (1990) Factors affecting the evolution and behavioral ecology of the modern bears. Int Conf Bear Res Manage 8:189-204

Stirling I, Spencer C, Andriashek D (1989) Immobilization of polar bears (Ursus maritimus) with Telazol in the Canadian Arctic. J Wildl Dis 25:159-168

Stirling I, Calvert W, Stirling I, Andriashek D, Calvert W (1993) Habitat preferences of polar bears in the western Canadian Arctic in late winter and spring. Polar Rec $(\mathrm{Gr}$ Brit) 29:13-24

Editorial responsibility: Yves Cherel, Villiers-en-Bois, France
Stirling I, Lunn NJ, Iacozza J (1999) Long-term trends in the population ecology of polar bears in western Hudson Bay in relation to climatic change. Arctic 52:294-306

* Stirling I, Spencer C, Andriashek D (2016) Behavior and activity budgets of wild breeding polar bears (Ursus maritimus). Mar Mamm Sci 32:13-37

* Stock BC, Semmens BX (2016) MixSIAR GUI user manual, version 3.1. https://github.com/brianstock/MixSIAR, doi: 10.5281/zenodo.56159

Thiemann GW, Iverson SJ, Stirling I (2008) Polar bear diets and Arctic marine food webs: insights from fatty acid analysis. Ecol Monogr 78:591-613

* Thiemann GW, Iverson SJ, Stirling I, Obbard ME (2011) Individual patterns of prey selection and dietary specialization in an Arctic marine carnivore. Oikos 120: 1469-1478

* Van der Putten WH, Macel M, Visser ME (2010) Predicting species distribution and abundance responses to climate change: Why it is essential to include biotic interactions across trophic levels? Philos Trans R Soc B 365:2025-2034

*Young BG, Ferguson SH (2014) Using stable isotopes to understand changes in ringed seal foraging ecology as a response to a warming environment. Mar Mamm Sci 30: 706-725

Young BG, Loseto LL, Ferguson SH (2010) Diet differences among age classes of Arctic seals: evidence from stable isotope and mercury biomarkers. Polar Biol 33:153-162

* Young BG, Ferguson SH, Lunn NJ (2015) Variation in ringed seal density and abundance in western Hudson Bay estimated from aerial surveys, 1995 to 2013. Arctic 68: 301-309

*Yurkowski DJ, Ferguson SH, Semeniuk CAD, Brown TM, Muir DCG, Fisk AT (2016) Spatial and temporal variation of an ice-adapted predator's feeding ecology in a changing Arctic marine ecosystem. Oecologia 180:631-644

Submitted: May 25, 2018; Accepted: March 20, 2019 Proofs received from author(s): May 15, 2019 